\section{RIRDS OF PASBAGE}

BY B. B. BOFDrsB.

It is a far cry from the day when Aristotle propounded the doctrine that birds hibernate like woodchucks, to the present time, yet much of the mystery which that early naturalist sought to dispel still lingers about the wonderful phenomena of migratory movement.

Only in birds (unless we except fishes) is true migration instinct found. Erratic, semi-migratory movements of insects take place; scarcity of food or some other strongly compelling cause induces, from time to time, a semblance of migration among some of the mammals, but only the winged and feathered inhabitants of the globe exhibit a seasonal rhythmic swing from south to north and vice versa.

Our modern knowledge embraces much data respectng the actual migratory movement, its date of commencement, duration, and termination; the termin of the journey, the route followed, and the manner in which the traveling is performed. We have accumulated a great mass of statistics concerning the time in spring and fall when certain feathered wanderers may be reasonably expected to appear at a given point along their route. We know that the method of performing these journeys varies much between species, as in length of flight that takes them from winter to summer homes and return, whether thoy fly almost continuously or by short, leisurely stages; whether flights are mostly by day or night or both; the route followed, and whether this is changed by varying weather or other conditions. We also know that certain species perform their flight to their northern summer homes along one route, and return to their southern winter homes by a widely different course. It is well established that some species flock and fly almost entirely by themselves, that others are found widely scattered among flocks of other species, that in still other cases two or three species may almost certainly be found flocked together, while in some instances the flight is performed more in an individual and straggling manner. It is a fact well known to many gunners

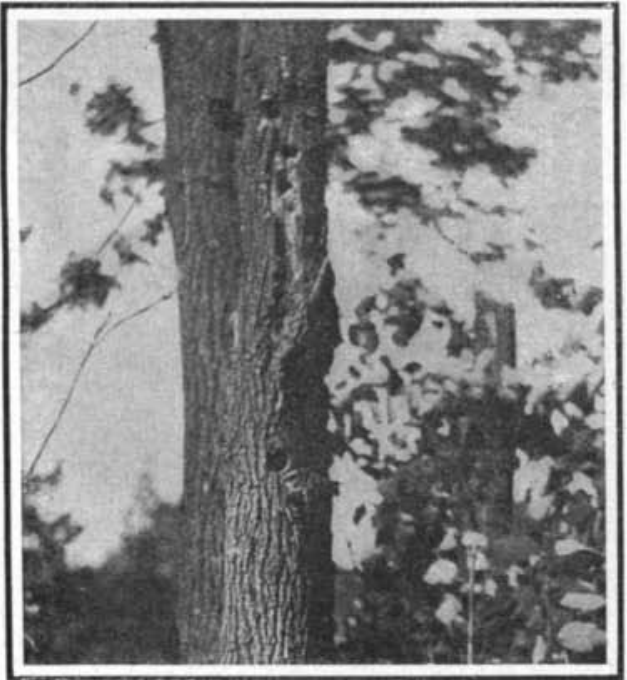

The downy woodpecker at home a non-migratory bird. that the course and manner of certain species of migrating birds has been changed materially within recent years, perhaps permanently, and that temporary changes of this character constantly occur, due to easily recognized causes. That class of birds whose life cycle is, perhaps, best known is naturally the one which includes those classed as game birds. Notably, as regards migration, these birds fall readily into three divisions: the water fowl, including ducks, geese; and swans; the Limicolæ or shore birds, principally the sandpipers and plovers; the gallinaceous birds such as the bob-white or quail and the ruffed grouse or partridge.

The southward fall 'migration of the first-mentioned division may, perhaps, be readily ascrib ed to search for wide and rich feeding areas, where open water is northern flight to a similar seeking of ample breeding grounds. While the southward flight is in some few instances continued as far as the West Indies and South America, in the main the movement is only sufficient and in general seems to conform to the cause assigned. In suitable localities on the New England coast and along Long Island we find an abundant representation of this division braving the rigors of winter, while in the wonderful breeding grounds along the coast of North Carolina, their numbers seem only to be limited by the persecution of the gunners. The northward journey of the members of this division, it is true, is for the most part, extended well into the Arctic or sub-Arctic regions, but this is largely a matter of necessity, to secure sufficient areas of suitable nature where they may breed in peace. Where birds of this division are not harrassed in late winter and spring by shooting, it has been found that they often remain in considerable numbers to breed, much further south than the usually ascribed southern limit of summer residence.

On the other hand, the migratory movement of the second division mentioned is one of the most extreme known. Such birds as the golden plover, black-bellied plover, buff-breasted sandpiper, and others of their kind are startling examples of the most wonderful mi gration flights. The golden plover, breeding within the Arctic Circle, often extends its quarters as far south as Patagonia. Of necessity the breeding season is short, but nearly six months is spent in winter homes. About four months of the year is spent in their spring and fall journeys, which are sometimes as much as 3,000 miles in length. In spring the travel northward via the Mississippi Valley, but in fall they go south by the way of Labrador and Nova Scotia from the latter point launching out to sea and in favorable weather often making a trip of 2,400 miles to South America without a known stop. Ther seems good reason to believe that this avoiding of our coast has increased in frequency since the shooting of the birds by the barrelful so reduced their numbers, and endangered a coastwise journey overmuch.

The black-bellied plover breeds equally far north and, on this hemisphere, winters in the West Indies, Brazil, and Colombia. The buff-breasted sandpipe summers as far north as the Arctic coast and winter south of Uruguay and Peru. Migratory movement in all such birds has been undoubtedly affected by changed coastal conditions and excessive shooting.

The third division represents birds that are practi-

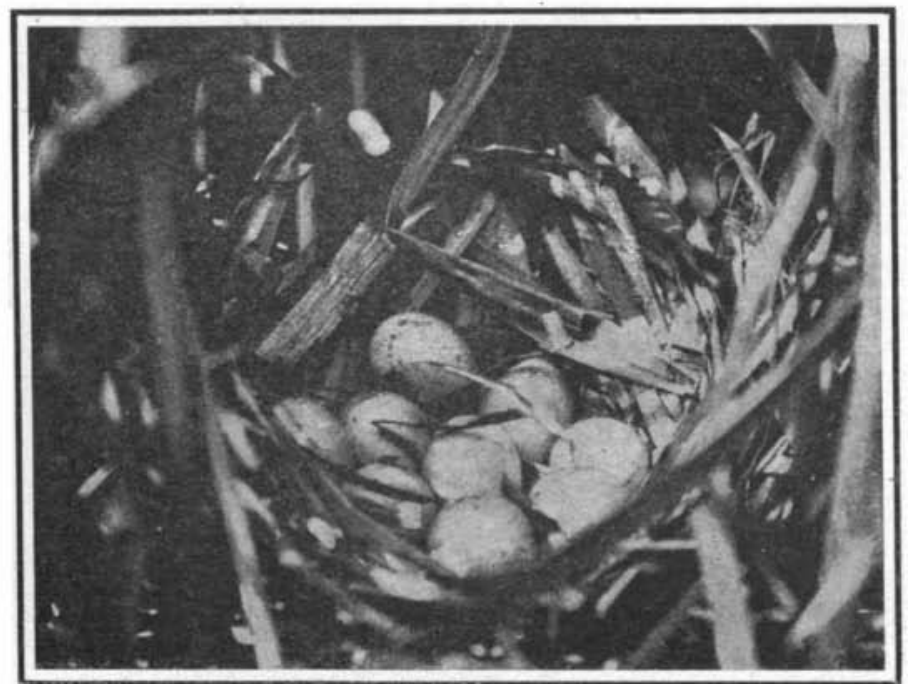

The nest of the Florida gullinule built for years in the same site, even after the marsh has become the center of a hustling city section.

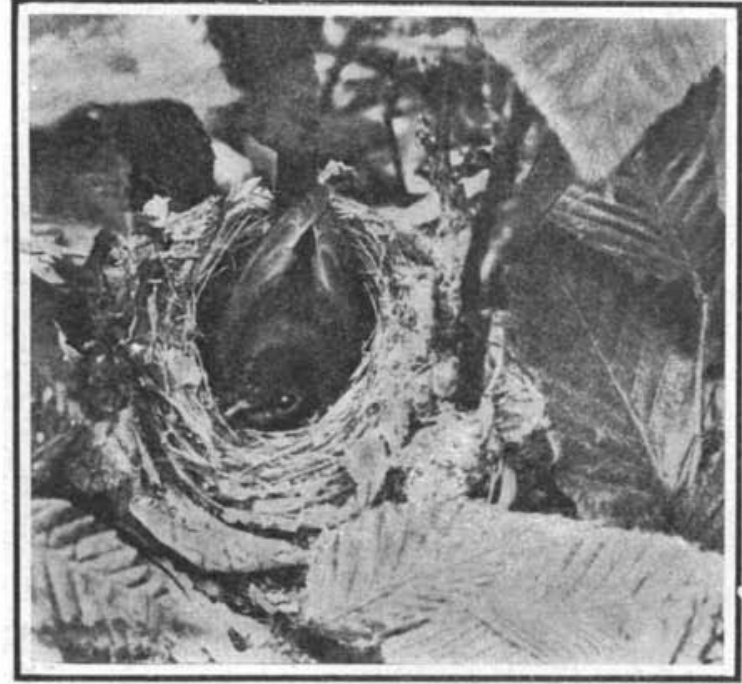

The hooded warbler and her.home, close to last year's abode.

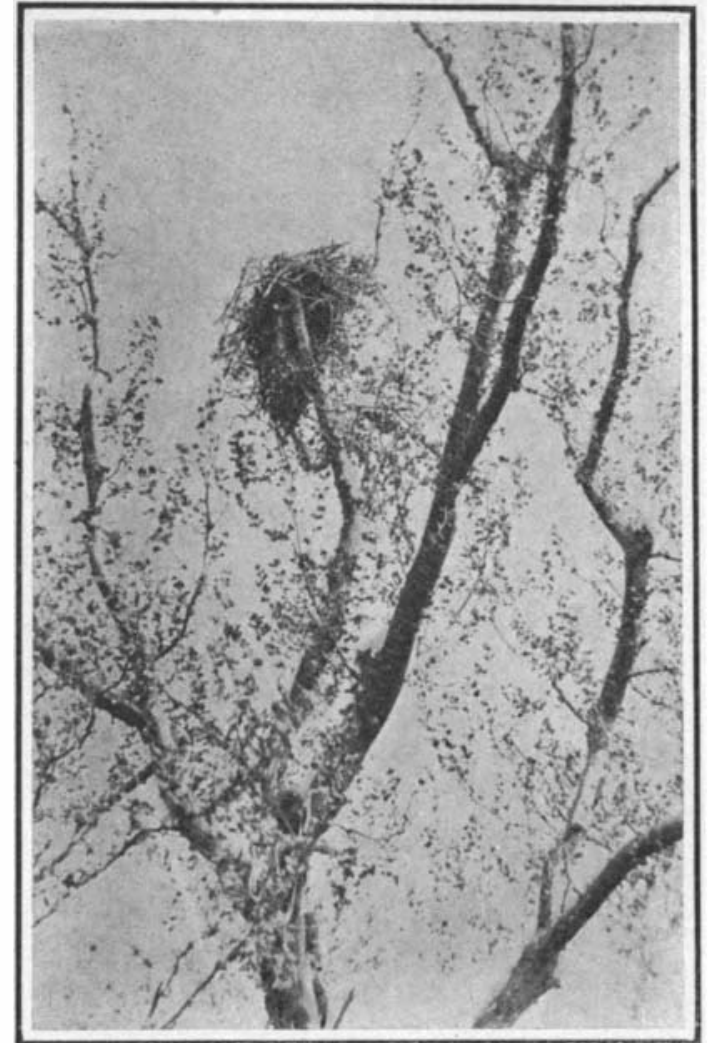

The osprey's nest to which the birds return year after year.

by birds in their journeyings north and south, has long been abandoned by the ornithologist. The question of food supply only offers partial solution. This is true of other tentative causes advanced. It seems probable that a number of causes in a great variety of combination contribute.

In the study of migration, one fact seems to be unmistakably established, namely, the existence of an extinct that enables birds in flocks or individually, to perform migratory flights of great length, and to return with great precision to the breeding spot of the previous year. Thus we find birds that breed gregariously, as gulls, terns, herons, and others, yearly returning to the same island, strip of beach, marsh, or swamp in a colony, and about the same time each year. In the same way our common birds that are more or less solitary in their nesting habits return in many instances to the same spot, year after year. The bridge girder, the beam in the cow-shed, or the molding on the porch pillar that has this year held a phœbe's nest, will, ten to one, hold such a nest next year. It is not exceptional to note on the limb of a village shade tree the occupied nest of the Baltimore oriole, the weathered last year's nest, and the battered remains of the nest of two years ago A last year's nest of the vireo is often a good clue to the immediate whereabouts of an occupied nest. Robins' nests are not infrequently built on the remains of the domicile of the year before. A hawk's nest is often used for many years in succession, and this is particularly the case with the fish hawk or osprey, whose nests, thus added to year by year, often become very bulky, with the underpart or foundation a crumbling mass of age-decayed matter. Woodpeckers, who seldom use the same nest twice, often have two or more excavations in the same stub, the nesting cavities of successive years.

All this evidence of a return of individual birds to a given locality is, of course, not absolutely conclusive It is seldom possible to adduce such conclusive evidence. The reasonable conclusion, however, must be (Continued on page 340 .) that the weight of evidence is in favor of the theory and the one which still figures largely in the popular mind, and seeking of a comparatively equitable climate

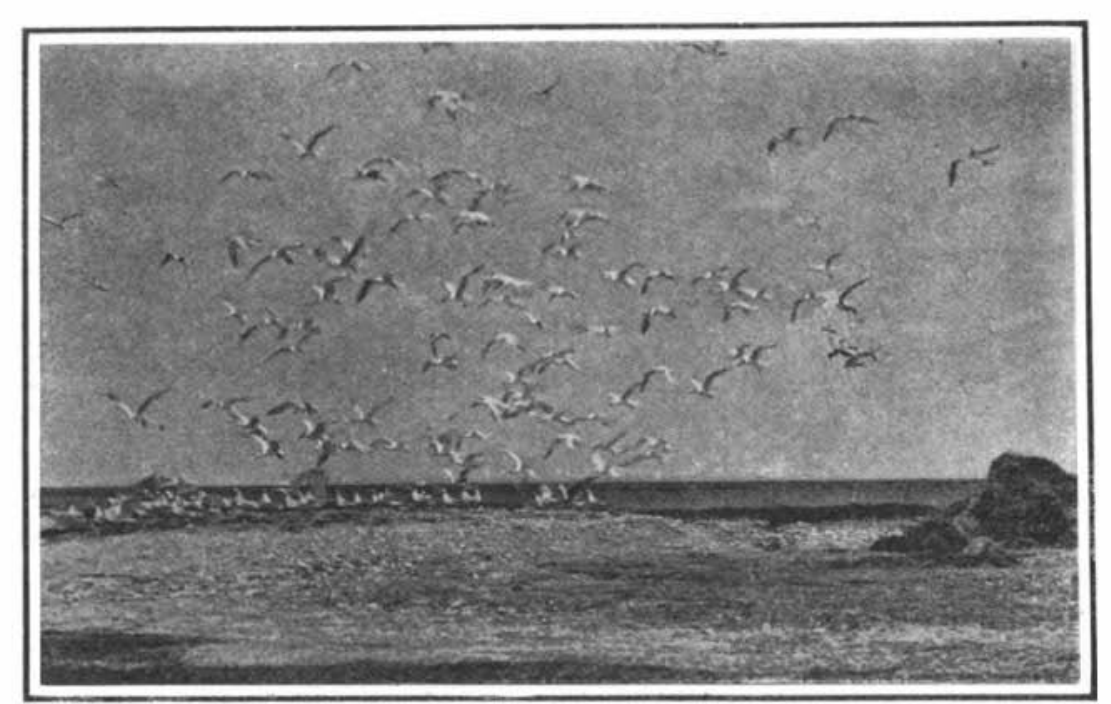

When the royal terns make their annual return to their island home.
BIRD MIGRATION 
and connected by compound positive clutches at both crank and main shafts, are fitted on the forecastle head for working the anchors.

The steam steering is of the Caldwell combined steam and hand type, with control shafting to the steering standard on the navigating bridge, and is placed in the engine-room casing. Hastie's handscrew steering is fitted aft immediately over the rudder head, for use in case the steam gear breaks down. On the starboard side a motor launch is carried under Welin bow davits, ready for immediate use for taking soundings or making observations.

\section{SOME CURIOSITIES OF INVENTION.}

(Concluded from page 339.)

by cork bulwarks $b$. We wonder if the inventor really believes in the efficacy' of the hand-operated screw propeller which he has provided.

The Society for the Prevention of Cruelty to Animals would undoubtedly in terest itself in restraining the inventor who devised the arrangement here shown to enable a dog or cat to run a sewing machine. We once heard of a man who patented a contrivance for driving a coffee mill by means of a bicycle, so that by the simple contrivance of riding a bicycle it was possible to obtain not only a certain amount of exhilarating exercise, but also to provide enough ground coffee for breakfast. This patentee surely outdoes bim. The dog is made to rotate a central shaft carrying a large gear wheel which meshes with a small bevel gear carried on the sewing machine driving wheel. It seems to us that after the dog had sewed one shirt he would be too dizzy to do much more; or perhaps when that occurs, the central shaft is to be driven in the opposite direction.

A grain of common sense is to be found in the trunk that becomes its own luggage trolley, for it must be confessed that the ordinary trunk when full is not the easiest thing in the world to handle The inventor has provided a single wheel and a folding. lever handle which serves the purpose of pushing the wheeled trunk along. He evidently was not concerned much with the problem of the amount of space consumed by the wheels and the handle when folded within the trunk.

The handle shown for carrying parcels used in carriages has been employed in European railways. The device consists simply of two straps and a rest board, with the whole easily detachable. Straps serve the purpose of binding the rest board and walking sticks. and umbrellas together.

A boat driven by windmills is certainly a mechanical curiosity. Just why this complicated arrangement of bevel gears connecting the propeller shaft with the vertical windmill shaft should be better than canvas transcends our imagi-

There is a touch of the Yankee in the fishing device, the last of the invention illustrated. Evidently the inventor was accustomed to fishing in streams wher bites were few and far between, and where patience was ill rewarded. He has contrived a fishing pole with a swinging arm carrying a clapper which is made to ring a bell as soon as a fish bites and swings the arm down.

\section{BIRDS OF PASSAGE}

(Continued from page 395. ) of the return of the same individuals Some wonderful European records of the return of a species to a given nesting site are given by the late Prof. Alfred Newton. A common falcon, Falco pere grinus, a cosmopolitan bird commonly known as the duck hawk, in this country, had its eyrie at one point in Finland for 110 years; that is to say, there was at this same point an occupied nest of this species from 1736 to 1855 . At Oxbridge in one or the other of two earthen bottle placed for their use, a pair of blue titmice had their nest every year, with two (Concluded on page 342.$)$

\section{STILL GROWING Over 210,000 Circulation}

LESLIE'S WEEKLY is growing in circulation, influence and advertising value-growing fast.

Over 200,000 people subscribe to or buy LESLIE'S WEEKLY each week because they want an illustrated newspaper and cannot get anything like it elsewhere.

Advertisers use LESLIE'S WEEKLY because they recognize it as the only paper in its class without a competitor in a highly profitable field.

Because in consequence they run less risk of duplicate circulation than in the multitude of other publications which aside from name are all about alike.

Because a big publication like LESLIE'S WEEKLY filled with the finest photographs depicting every important or nationally interesting event makes the best possible history of the world's progress and insures each weekly issue a longer life than most monthly magazines enjoy.

Advertisers who buy space now at the rate of 75 cents a line will get the benefit of this large and rapidly increasing circulation which is absolutely guaranteed.

\section{Advertising Department}

\section{LESLIE-JUDGE COMPANY}

Western Office
1136-37 Marquette Building
CHICAG0, ILL.

\section{Fifth Avenue and 27th Street Brunswick Building NEW YORK}

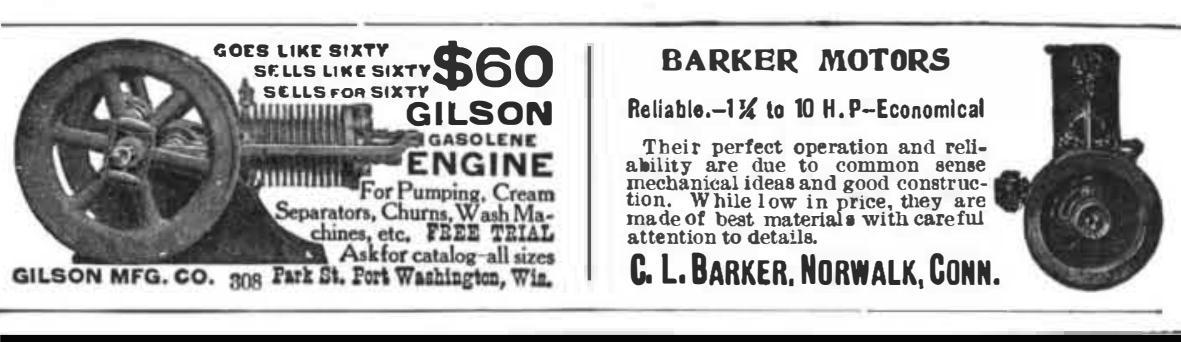

Just Published-A BOOK OF INTEREST TO RIFLEMEN

\section{The Bullet's Flight from Powder to Target}

The Internal and External Ballistics of Small Arms. A Study of Rifle Shooting with the Personal Element Excluded, Disclosing the Cause of the Error at the Target.

Illustrated with one hundred and eighty-eight plates, showing the results of over three hundred rifle experiments performed and chronologically arranged

By F. W. MANN, B.S., M.D.

Size $7 \frac{1}{2} \times 93 / 4$ inches. 384 Pages. Price $\$ 4.00$ post paid

THIS is a thoroughly practical treatise and deals with a subject the literature of which is not commensurate with its

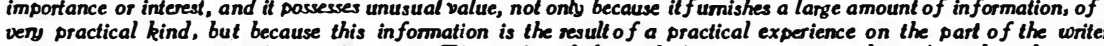
atren astenlly and laboriously worked out with an earnest desire to assist his fellow marksmen. In view of the fact that conjecturing either been proved to be false or have been fully substantiated by recorded experiments. Mast of the illustrations are photo
graphic reproductions of the results of actual tests. Every page is full of interest for the rifle enthusiost. There is a fult discussion of various kinds of riftes, of the effect of difference of length, of variations of rifling, elc.s as wedl as of instruction

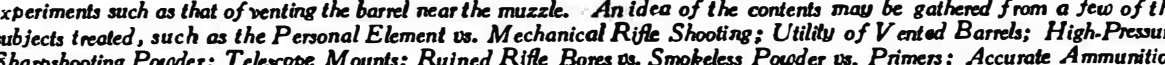

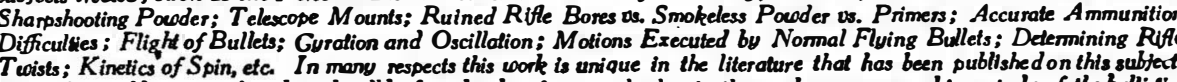

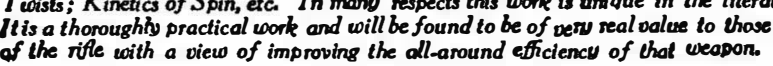

MUNN \& COMPANY, Inc., Pablishers, 361 Broodway, New York City

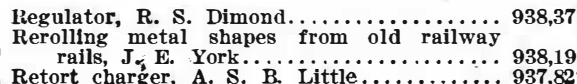

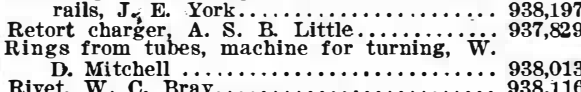

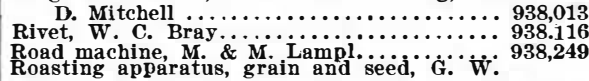

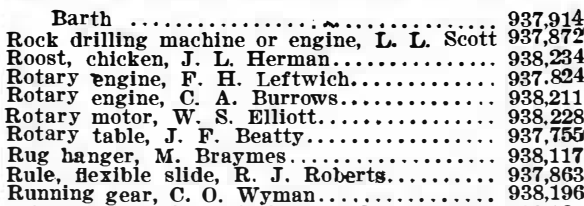

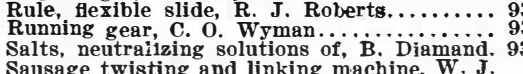

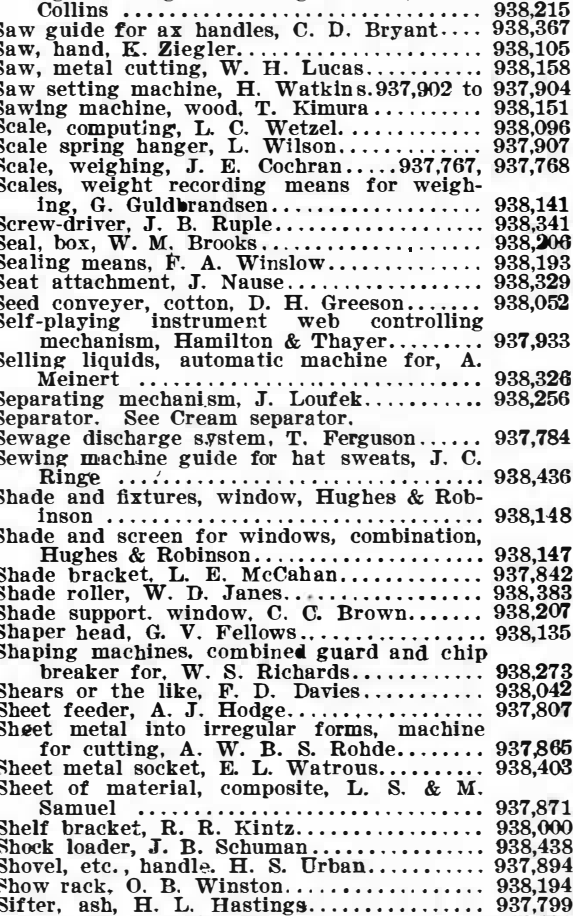

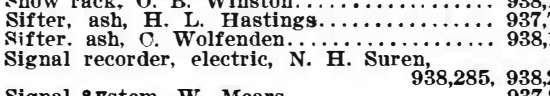

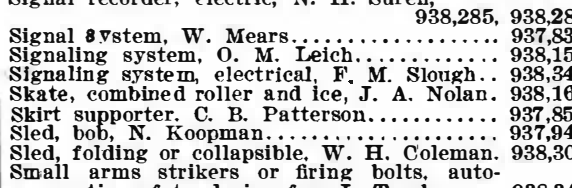

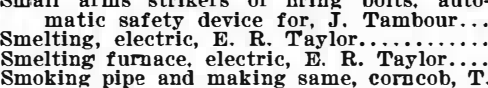

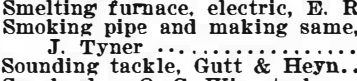

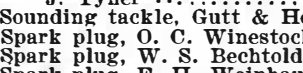

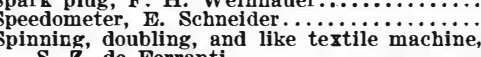

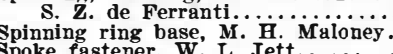
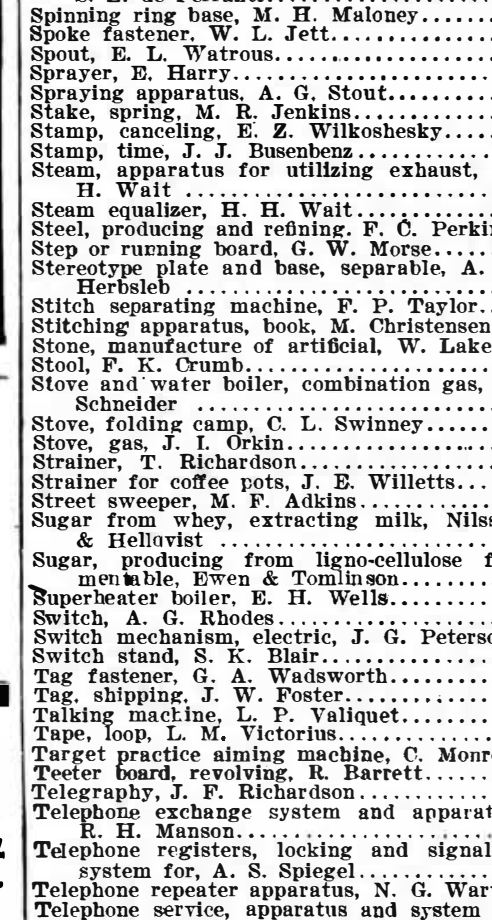

lizer, H. H. Wait ............. 938,35
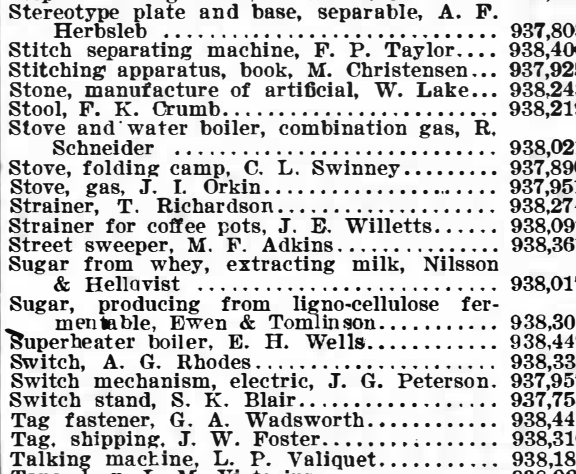

\section{T.}
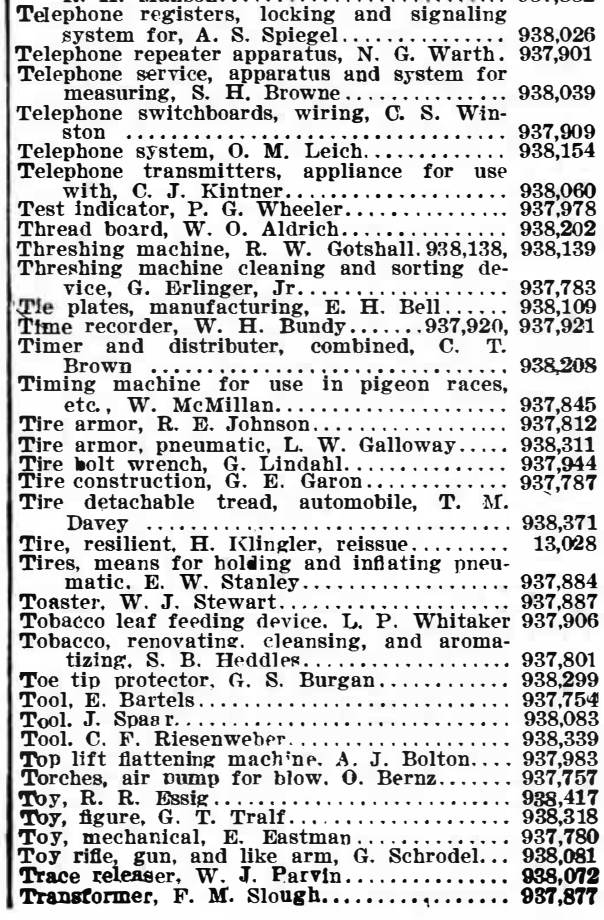
